\title{
The Structure, Conduct and Performance of REITs in Emerging Markets: Empirical Evidence from Nigeria
}

\author{
Daniel Ibrahim Dabara1, and Olusegun Adebayo Ogunba2
}

1 Department of Estate Management, Federal Polytechnic Ede, Nigeria.

2 Department of Estate Management, Obafemi Awolowo University, Nigeria.

To cite this article: Dabara, D.I. \& Ogunba, O.A. (2019). The Structure, Conduct and Performance of REITs in Emerging Markets: Empirical Evidence from Nigeria. Journal of African Real Estate Research, 4(2), pp.76-97. DOI: 10.15641/jarer.v4i2.827.

\begin{abstract}
Purpose: This study examines the correlations between the structure, conduct and performance of Real Estate Investment Trusts in Nigeria (N-REITs) with a view to providing information that will enhance and guide real estate investment decisions on N-REITs.

Design/Approach: The study population consists of all three REIT companies in Nigeria, namely: Skye Shelter Fund, Union Home REIT and UACN Property Development Company (UPDC) REIT. Secondary data on dividends and share prices of N-REITs; Total Business Revenues (TBR) and Total Individual Expenditure (TIE) on conduct variables were sourced from periodicals of the respective companies covering the period from 2008 to 2016. The data series for the study were analyzed by means of the Kwiatkowski-Phillips-Schimidt-Shin (KPSS) unit root tests, Philip-Perron (PP) unit root tests, Granger Causality tests, and the Ordinary Least Square (OLS) regression.

Findings: The study shows a Herfindahl Hischman Index (HHI) that ranged between $41.81 \%$ (recorded in 2010) and 100\% recorded in 2008. This suggests a high concentration in the NREITs industry. Similarly, the Granger Causality test conducted reveals a bi-directional causal relationship between the structure, conduct and performance of N-REITs.

Practical Implications: The study provides essential information (on the HHI, return performance and causal relationships) for stakeholders in the real estate sector regarding the influence of structure and conduct on the performance of N-REITs. This information will be valuable for equipping asset managers, insurance companies, pension funds and individual real estate investors in making informed investment decisions.
\end{abstract}

Originality/Value: This study is unique as it is the first to draw a link between the structure, conduct and performance of REITs in an African emerging real estate market; something that has not been considered in previous studies.

Keywords: Real Estate Investment Trusts; Conduct; Structure; Investment Performance; Real Estate; Nigeria 


\section{Introduction}

The Structure, Conduct and Performance (SCP) framework was pioneered by Mason (1939) and Bain (1951). It has since become one of the most effective models used in analysis of the causal relationships among the structure, conduct and performance of various industries. The central hypothesis of the model posited that structural characteristics of an industry determines the conduct (behavior) of companies in the industry, which subsequently affects the industry's performance. The model has been modified over time to suit diverse industries and to include variables beyond the purview of Mason and Bain's ideas (Kaonga, 2015). Since its inception, it has been used to analyze industries including, but not limited to; banking, manufacturing, agriculture and real estate, among others.

Real Estate Investment Trusts (REITs) were first introduced in the United States of America in 1960. The purpose of the creation of REITs is to provide opportunities for all categories of investors to enjoy the advantages and benefits of investing in real estate without actually being involved directly in the real estate development process (Naido, 2014). Manoj (2016: p.156) posited that a "REIT is a trust that pools capital from various investors and uses same to purchase and manage income producing real estate or real estate related assets." REITs can be classified into: equity, mortgage and hybrid (Seguin, 2016).

Drew (2016) asserted that REITs have become one of the vital investment vehicles in the economy of many countries. This is shown by the amount of investments in REITs industries across the globe. For example, Aro-Gordon, Bashir, Abdulsalam and Abdullahi (2014), Li and Chow (2015), NAREIT (2018) and NAREIT (2019) revealed that in 2012, REIT market capitalizations for the US was $\$ 400$ billion; Singapore was $\$ 30.5$ billion; and Japan was $\$ 42$ billion (Aro-Gordon et al., 2014). In 2013, the estimated global REITs capitalization was about $\$ 1.1$ trillion ( $\mathrm{Li} \&$ Chow, 2015). In 2016 the global REITs market capitalization was estimated at over \$2 trillion and more recently (2018/2019) it was estimated at over \$3 trillion (NAREIT, 2018; NAREIT, 2019). Despite the fact that REITs are said to be one of the viable and profitable investment asset classes in global markets (Jackson, 2008), it has been observed that REITs are underperforming in Nigeria (Akpan \& Ogunba, 2015; Dabara et al., 2018). The first Nigerian Real Estate Investment Trust (N-REIT) was introduced by the Skye Shelter Fund in 2007 with an IPO (Initial Public Offering) capitalisation of $\$ 2$ billion $(\$ 6,535,948)$. In 2008, Union Home Hybrid REITs was similarly created with an IPO capitalisation of $\$ 50$ billion $(\$ 163,398,623)$, while the UPDC (UACN Property Development Company) REITs was introduced in 2013 with an IPO capitalisation of $\$ 30$ billion which was estimated at $\$ 98,039,216$. From the three companies, only the Skye Shelter Fund was able to raise the IPO capitalization that was targeted ( 2 billion), which is equivalent to $\$ 6,535,948$. Both the Union Home REITs and the UPDC REITs could not raise the total capitalization targeted. The Union Home REITs raised 12,500,986,050 (\$40,852,896); while the UPDC REITs raised 
\$26,682,695,000 (\$87,198,350) during their respective IPO’s (Skye Shelter Fund, 2007; Union Home REIT, 2008; UPDC REIT, 2013).

In Nigeria, the Security Exchange Commission (SEC) is the regulatory body saddled with the responsibility of regulating the activities in the REITs industry. The operational and regulatory guidelines for N-REITs as stipulated by SEC are: a property requirement which mandates a $75 \%$ real estate investments in the N-REITs portfolio; at least $75 \%$ of income should be regenerated from real estate or real estate related assets; $90 \%$ distribution requirement of taxable profit to unit holders; exemption from tax; management must be overseen by a board of directors or trustees; the company's shares must be fully transferrable and the company should have a minimum of 100 shareholders. N-REITs derives its income from real estate investments that are mostly residential and commercial properties; predominantly in Lagos, Abuja and Port-Harcourt. Real estate plays an integral role in the country's economy. It is Nigeria's fifth biggest contributor to GDP with a contribution of about $6.5 \%$ to Nigeria's GDP (Nigerian Bureau of Statistics, 2018; Dabara et al., 2019).

Previous studies, such as Akpan and Ogunba (2015), Olanrele, Said and Daud (2015) and Dabara et al. (2018), revealed that all the N-REITs companies provided low, and in some cases, even negative return values on investment. This has negatively impacted on the N-REITs industry by impeding the growth of the industry and patronage from both domestic and foreign investors. This scenario is quite contrary to what was found in literature on the performance of REITs in other parts of the world (Jackson, 2008; Manoj, 2016). The problem is exacerbated and becomes more perplexing by the fact that the property assets in Nigeria (from which REITs derive their income) are performing well in terms of returns on investment (Dabara, Ogunba \& Araloyin, 2015; Dabara \& Oyewole, 2015). This is also a true reflection of the performance of real estate in other African countries. For example, a study carried out in South Africa by Ntuli and Akinsomi (2017) revealed that REITs are good return-enhancers and also have diversification benefits in a mixed asset portfolio. Similarly, a study conducted by Olanrele (2014) found that economic factors influence the performance of REITs. Dabara et al. (2018) in a more recent study found that the financial structure of REITs impacts greatly on REITs performance.

Questions have begun to emerge surrounding the possible causes of the underperformance of N-REITs. In order to answer to these questions, it is important that empirical research be carried out which will determine why the performance of N-REITs is contrary to what was found in the literature. Additionally, the research aims to provide insight into the factors causing the poor performance of N-REITs. This is important as Nigeria is largely regarded as one of the fastest growing economies in Africa. Nigeria is also considered as one of the top ten most improved on the Ease of Doing Business ranking across global economies in the world, thereby making it a good playing field for both domestic and foreign investments in the real estate sector (Ankeli et al., 2017). Furthermore, the N-REITs industry is still new with only three REIT companies whose major investments focus is mainly in 
commercial and residential properties. Similarly, the fact that N-REITs fall under developing markets is another motivation for this study. However, there is dearth of data on N-REITs to assist investors, hence, this study will add to the scanty existing research work in yet another important African emerging real estate market (Nigeria). The study adapts Bain's (1951) SCP theory as a major initial underpinning to addressing the research problem in this study. The theory purports that there is a one-way causal relationship between the structure (characteristics of an organization e.g. market structure), conduct (the actions or behavior of a firm in the market e.g. advertisement) and performance (the outcome or results obtained from a firm e.g. returns).

This study, which aims at examining the correlations among the structure, conduct and performance of N-REITs, to the best knowledge of the researches, is the first study that draws a link between the structure of the Nigerian REITs industry, its conduct, as well as its performance. This is because the SCP theory postulates that if there are faults in the structure of an industry, this affects the conduct of that industry, which in turn affects the performance of the industry. Hence, this paper attempts to establish the relationship between N-REITs and the SCP paradigm. To the best knowledge of the authors, no study had looked at REITs performance vis-a-vis its structure and conduct. This paper makes a contribution to the REIT literature by extending the frontier of knowledge as it fills this gap. The study examines the following research question: what is the relationship and effect of the REIT industry structure and conduct on REIT performance in Nigeria? The rest of the paper is organized as follows: section two reviews relevant literature; section three presents the methodology adopted for the study; section four presents results and discussion of results while section five presents conclusion of the study.

\section{Literature Review}

Most of the REIT literature focuses on performance related to inflation hedging, diversification, return/risk, dividend yield and capital gains. Jackson (2008) asserted that REITs are one of the most viable and profitable investment asset classes in global real estate markets. This is evident in the performance of REITs in most developed economies, such as the US, UK, and Germany, among others (NAREIT, 2018). Some developing economies such as Malaysia, Taiwan and Thailand are also doing well. However, REITs in most developing nations, particularly African nations, are still new and characterized by property market immaturity, non-availability of data for investment decisions and challenges of liberalization and integration into the global market (Bekaert, Harvey \& Lundblad, 2003; Dabara et al., 2018).

It is obvious that maximizing profits is the objective of rational investors. To achieve this, investors and researchers all over the world are assessing the investment performance of various asset classes. In the real estate sector (specifically REITs), a group of studies have examined the inflation-hedging potentials of REITs. These studies include Kloosterman (2009), Aik (2012) and Dabara et al. (2019). Kloosterman (2009) found some hedging 
effectiveness against unexpected inflation for all REITs and Equity REITs in the US. Aik (2012) compared conventional and Islamic REITs performance in Malaysia. Findings from the study revealed that REITs underperformed during and immediately after the global financial crisis experienced around 2008. Dabara et al. (2019) found perverse hedging characteristics associated with investments in N-REITs. Similarly, studies such as Khoipham (2013) examined the investment performance of Asian REITs in a mixed-asset portfolio from 2001 to 2012. Findings from the study indicated that REITs provided strong diversification benefits for the mixed-asset portfolio. This is in agreement with the findings of Naidoo (2014). Another group of studies have evaluated the performance of REITs in terms of their risk/return characteristics. Such studies, including Akpan and Ogunba (2015), revealed that investments in N-REITs were underperforming in terms of total returns, total risk and risk-adjusted return. This is not in agreement with the findings of Niskanen (2012), which asserted that REITs provide good returns on investments. More recently, studies such as Olanrele, Adegunle and Fateye (2018), investigated the correlations between REITs and Money Market Indicators, such as Treasury Bills, among others. The Granger Causality tests conducted in the study revealed an insignificant long-run causal relationship, but a significant short-run causal relationship between N-REITs returns and Money Market Indicators.

A group of studies conducted in South Africa by Akinsomi et al. (2016) investigated the performance of the Broad Based Black Economic Empowerment (BBBEE) of both listed and delisted property firms in South Africa. The study covered the period from 2006 to 2012 . The return and risk performance of the property firms were obtained by means of holding period returns formulae, capital asset pricing model, sharpe ratio and alfa, among others. Findings from the study revealed that BBBEE compliant firms outperformed the non-BBBEE compliant firms with respect to both returns and risk performance. Similarly, Akinsomi et al. (2017) revealed that speculation in the gold market has an impact on REIT returns in South Africa, particularly during the global economic meltdown experienced around 2008 to 2011. In the same vein, Ntuli and Akinsomi (2017) found that South African REITs are good return-enhancers with diversification benefits, which could encourage shrewd investors to consider its inclusion in their mixed asset portfolios. Another study conducted in South Africa by Ijasan, Tweneboah and Mensah (2017) showed evidence of anti-persistence in South African REIT returns. With the earlier authors' analysis of performance of REITs, the current study focuses on a new perspective of the SCP paradigm by unravelling the relationship of the structure, conduct and performance in the REIT industry in Nigeria.

Bain (1951) conducted the earliest study on the structure, conduct and performance (SCP) framework. The study examined the relationship between the market structure of manufacturing industries in the US using variables such as buyers and sellers' concentration, level of product differentiation as well as condition of entry/exit from the market and how it relates to the conduct as well as the profit rate of the companies in the industry accordingly. Data for the study covered the period from 1936 to 1940. The methodology 
involved the use of both $\mathrm{z}$ test and regression analysis. Findings from the study indicated that firms/industries with higher levels of concentration (above 70\%) recorded higher profits. Ferguson (1998) argued that the Bain's theory has some limitations, which borders on the complexities associated with firms and industries. Hence, the author is of the opinion that the SCP framework could be linked to other factors rather than restricting it to only structure, conduct and performance. To buttress this assertion, Matyjas (2014) posited that the SCP paradigm can be modified to go beyond the scope of structure, conduct and performance variables, and could also include other variables such as government policies and other basic conditions including location and technology. This was in agreement with an earlier studies conducted by Porter (1981).

Delorme et al. (2002) examined the correlations between structure, conduct and performance of manufacturing industries in the US in 1982, 1987 and 1992. The study found that the conduct of the manufacturing industry in the study area (proxied by advertising) do not influence the profitability in the industry. Tung et al. (2010) examined the performance of the tourist hotel industry in Taiwan using the SCP paradigm. Data was obtained to cover a period spanning 1995 to 2006 . Findings from the study revealed that the profitability or performance of the the hotel industry in the study area was significantly influenced by the market structure of the industry. The paper focused on only direct investment in real estate (hotels) and did not consider investment in indirect real estate, such as REITs.

For the application of the SCP framework in real estate in Nigeria, Ogunba (2004) examined the conduct of valuation exercises in Nigeria using Bain's (1951) SCP model which was subsequently modified. The study proxied conduct of valuation exercises using variables relating to the valuer's use of investment valuation inputs and some unconventional manipulations of data amongst valuers. The methodology adopted in the study used descriptive statistical tools, such as mean, percentages, and charts in analyzing the data. Findings from the study revealed that valuation inaccuracy, which was observed to exist in the study area, arises due to the way the valuation exercises were conducted in the valuation profession. The results showed that the conduct of valuation exercise in the study area was characterized by nonuniformity of valuation inputs used by valuers as well as the observable practice of valuers resorting to unconventional manipulation of data. This result aligns with Chan, Erickson, and Wang (2003) in a similar study that investigated the structure, performance and investment opportunities in the REITs industry. Lee (2012) evaluated the performance of accounting firms (a service industry) in Taiwan from 1992 to 2003 using the SCP model. The study used the stepwise regression model in the analysis of the data obtained for the study. Findings from the study revealed that there was a significant relationship between market structure, conduct and performance of accounting firms in the study area. Nabieu (2013) analyzed the structure, conduct and performance of commercial banks in Ghana over a period from 2007 to 2012 using the SCP model. Both descriptive (mean, percentages, standard deviations) and inferential (regression) statistical models were used in the study. Findings from the study suggested that market structure and 
conduct significantly determined the performance of commercial banks in Ghana within the study period. This is congruent with a similar study conducted by Gavurova, Kocisova and Kotaskova (2017), which examined the structure and performance of European Union (EU) banking markets using the SCP paradigm. The main problem or gap observed from these studies is the dearth of studies in African real estate markets that look at the performance of REITs from the perspective of the conduct, structure and performance of REIT companies. Therefore, this present study will extend the frontier of knowledge in this field by considering the correlations among the structure, conduct and performance of N-REITs.

\section{Methodology}

To interpret the SCP model, Bain (1951: p.304) defined structure as "characteristics of an organization which seems to influence strategically on the nature of competition and pricing within a particular market". Ray (1992: p.68) on the other hand, explained that in the SCP model "structure represents a firm's internal characteristics which include: market share, entry barriers of new firms and number of buyers and sellers (i.e. concentration)". The structure of a firm or industry is found by its Herfindahl-Hirschman Index (HHI). This is obtained by calculating the firm's individual market share (using the Total Business Revenue data i.e TBR) which is subsequently translated into its concentration ratio and finally calculated as the HHI. The concentration ratio is usually calculated from census data which shows market shares of the said firms. The firm concentration ratio is calculated by the addition of the market shares of the nth largest firms found in the same market. While the HHI is calculated as the addition of the squares of the percentage market shares of the firms within a market (Scherer \& Ross, 1990; Matyjas, 2014).

In line with previous studies such as Kaonga (2015), the market structure for this study was obtained by using the total business revenues obtained by each of the N-REITs companies over the study period to calculate the market shares of the respective companies. These were subsequently translated to the concentration ratio of the N-REITs industry and the HHI which shows the type of market structure of the industry. Studies, such as Abdul Majid and Sufian (2007) and Bhandari (2010), posited that the major market structure types comprise of: perfect competition1; monopoly2; oligopoly3; and monopolistic competition 4 .

Tung et al. (2010) posited that in the SCP analysis, conduct is measured by any activity undertaken by a company or firm to improve its performance,

1 characterized by many buyers and sellers, identical products, no price regulation in the market, free entry and exit in the market and sellers and buyers having adequate information about the product

2 characterized by only one seller or producer, no substitutes for product, restriction to entry into the market and the seller or producer have complete control over price of the product 3 characterized by only few sellers or producers, similar or identical products, the market is very difficult for other producers to enter and firms are mutually dependent

4 characterized by large number of buyers and sellers, product differentiation, and free entry and exit of firms 
such as: advertisement, innovations, marketing strategies, research and development, etc. This study used relevant conduct variables in the N-REITs industry that have available data for analysis. These include: advertisement, property maintenance, insurance of properties, and administrative expenses. In this study, advertisement is defined as private or public notices which are designed to inform and motivate the buying behavior of the recipient by the advertisers to persuade the former to make decisions or take actions that the latter desired. This can be by means of television, radio, telephone, text messages, bill boards, etc. (Macarena \& Davide, 2014). Property maintenance involves overall upkeep of landed properties which may include specific or general repairs, installation of fixtures, etc. Property insurance is a policy that provides financial reimbursement to the owner or renter of a structure and its contents in the event of damage (Surminski, 2014). While administrative expenses in this study includes all expenses incurred by the company that are vital to the company's success as well as impacting positively on the performance of the company. These include: management fee, AGM (Annual General Meeting) expenses, sitting allowance, professional fees (auditors, lawyers, valuers, etc.), bank charges, subscriptions and donations, travelling expenses, etc. In line with studies such as Dabara (2015) and Akpan and Ogunba (2015), the performance component of this study was measured using the holding period returns. The holding period return captures both changes in dividends and capital growth of the investment asset in question. For this study, holding period return= capital growth of share prices (capital return) + income return.

The study population consists of all the REITs in Nigeria, namely: Skye Shelter Fund REIT, Union Home REIT and UPDC REIT. Data required for the structure of N-REITs comprised of the Total Business Revenue (TBR) of the N-REIT companies within the study period (2008 to 2016). This data was sourced from the annual reports and accounts of the respective N-REITs. Data required for the conduct component of N-REITs comprised the Total Individual Expenditure (TIE) on conduct variables proxied by factors, such as: advertisement, maintenance of properties, insurance of properties and administrative expenses. This data was also sourced from the annual reports and accounts of the respective N-REITs for the study period. Data required for the performance of N-REITs comprised of dividend and growth in share prices of the respective companies.

Descriptive and inferential statistical tools, such as: averages, frequencies, mean scores, as well as Ordinary Least Square (OLS) regressions were used in analyzing the data obtained. The structure of the N-REITs industry was analyzed by means of Equations 1, 2 and 3 in a chronological order. That is, the market structure of a company which is proxied by the HHI in line with previous studies such as Tung et al. (2010) and Kaonga (2015) was calculated accordingly by firstly obtaining the market share using Equation 1. Secondly, the market share was used to obtain the Concentration Ratio using Equation 2; and finally, the market structure of the company was obtained using the Concentration ratio to calculate the HHI by means of Equation 3. The Market Share is given as: 


$$
M K S=\frac{T B R(n 1)}{T B R(n 1+n 2+n 3)}
$$

Where:

$M K S=$ Market share

$T B R=$ Total business revenue for a particular REITs company

$n 1, n 2, n 3=$ Individual $N$-REITs companies

The Concentration Ratio is given as:

$$
\mathrm{CR}_{n}=\mathrm{MKS}_{1}+\mathrm{MKS}_{2}+\mathrm{MKS}_{3}
$$

Where:

$C R_{n}=$ Concentration ratio of $N$-REITs companies

$M K S_{1-3}=$ Market share of individual N-REITs companies

The Herfindahl-Hirschman Index is given as:

$$
\mathrm{HHI}=\sum_{i=1}^{n}(M K S i)^{2}
$$

Where:

$H H I=$ Herfindahl-Hirschman Index

$M K S i=$ Market share of the ith N-REITs company

$n=$ Total number of $N$-REITs companies

$i=$ The ith N-REITs company (e.g. UPDC REITs)

According to Kwoka (2007), the HHI ranges from $1 / \mathrm{N}$ to one, where $\mathrm{N}$ is the number of companies in the market or industry. If percentages are used as whole numbers (for example: 85 instead of 0.85 ), the HHI index can range up to 1002 , or 10,000 . The decision rule is that an HHI below 0.01 (or 100) indicates a highly competitive industry. An HHI below 0.15 (or 1,500) indicates unconcentrated industry; an HHI between 0.15 and 0.25 (or 1,500 to 2,500) indicates moderate concentration, while an HHI above 0.25 (above $2,500)$ indicates high concentration.

The data required for conduct variables consisted of data on the companies' conduct or style of operation in the capital market which was proxied by factors such as advertisement, property maintenance, insurance of properties, and administrative expenses of the 3 N-REIT companies for the study period. The TIE and TBR for the N-REIT companies were used to calculate the conduct indicators using Equation 4. This is congruent with previous studies such as Kambhampati (1996) and Bhattacharya (1997). The conduct equation used is as follows:

$$
X n=\frac{\mathrm{TIE}}{\mathrm{TBR}}
$$

Where:

$X n=$ Individual Conduct Indicator (e.g. advertisement)

$T I E=$ Total Individual Indicator's expenditure

$T B R=$ Total REITS Company' Business Revenue for individual REITs company

Similarly, the researchers used Equation 5 to measure the holding period return of the N-REIT companies. The holding period returns is expressed as:

$$
\mathrm{HPR}=\frac{N I t+\left(C V_{t}-C V_{t-1}\right)}{C V_{t-1}}
$$


Where:

$H P R_{t}=$ Holding Period Return

$C V_{t-1}=$ Share price of $N$-REITs at the beginning

$C V_{t}=$ Share price of $N$-REITs at the end

$N I_{t}=$ Income (Dividend) of N-REITs received during the holding period

Furthermore, the researchers analyzed the correlations among the structure, conduct and performance of N-REITs. To realize this first, unit root test (test of stationarity) of the datasets used in the study was carried out using the Kwiatkowski-Phillips-Schmidt-Schin (KPSS) as well as the Philip-Perron (PP) models for analyzing the stationarity characteristics of the data series. Second, the Granger Causality analysis was conducted to determine the causal relationships among the structure, conduct and performance of $\mathrm{N}$ REITs within the study period. Third, the relationships among the structure, conduct and performance of N-REITs in line with previous studies on the SCP concept, such as Tung et al. (2010) and Kaonga (2015), was determined using OLS regression models.

Decision rule for stationarity test:

If KPSS Statistics > KPSS critical value, do not reject null hypothesis, i.e., unit root exists (non-stationary).

If KPSS Statistics < KPSS critical value, reject null hypothesis, i.e., unit root does not exist (stationary).

If PP Statistics > PP critical value, do not reject null hypothesis, i.e., unit root exists (non-stationary).

If PP Statistics < PP critical value, reject null hypothesis, i.e., unit root does not exist (stationary).

Decision rule for Granger Causality tests:

If P-Value > 0.05, do not reject the null hypothesis of no Granger Causality (there is no causal relationship).

If $\mathrm{P}-\mathrm{Value}<0.05$, reject the null hypothesis of no Granger Causality (there is a causal relationship).

In line with previous studies, such as: Delorme et al. (2002); Tung et al. (2010); Nabieu (2013); and Kaonga (2015), the model specification for the regression model adapted for endogenous variables of Structure (STR), Conduct $(\mathrm{CON})$ and Performance (PER) in this study is given as follows:

$$
\begin{aligned}
& S T R=f(C O N, P E R) \\
& C O N=f(S T R, P E R) \\
& P E R=f(S T R, C O N) \\
& S T R=a 0+b_{1} C O N+b_{2} P E R+e_{1}
\end{aligned}
$$

Where:

STR $=$ Structure of N-REITs

$a 0=$ The intercept

$b_{1}=$ Conduct

$b_{2}=$ Performance

$e_{I}=$ The error term 


$$
C O N=a_{0}+c 1 S T R+c 2 P E R+e_{2}
$$

Where:

$\mathrm{CON}=$ Conduct of N-REITs

$\mathrm{a} 0=$ The intercept

$\mathrm{c}_{1}=$ Structure

$\mathrm{c}_{2}=$ Performance

$\mathrm{e}_{2}=$ The error term

$$
P E R=a_{0}+d_{1} C O N+d_{2} S T R+e_{3}
$$

Where:

PER $=$ Performance of N-REITs

$\mathrm{a} 0=$ The intercept

$\mathrm{d}_{1}=$ Conduct

$\mathrm{d}_{2}=$ Structure

$\boldsymbol{e}_{3}=$ The error term

\section{Results and Discussion}

This section presents and analyzes the data collected for the study. Table 1 presents the TBR for the N-REIT industry.

Table 1 presents the annual TBR for the N-REIT industry which was calculated as the summation of the annual revenues of the three N-REIT companies for each investment year accordingly. Similarly, the total share units subscribed and fully paid for by investors was presented in Table 1.

From Table 1, the highest TBR for the N-REIT industry was obtained in the year $2015(\$ 6,907,443,855$ i.e $\$ 22,573,345)$. The least TBR for the industry was obtained in 2008 ( $\$ 594,417,008$ i.e $\$ 1,942,539)$. This could be attributed to the economic recession experienced in the country around that period. There was a gradual decrease in TBR generated from 2009 to 2011 (this was the period of the global economic meltdown). In 2012 there was a slight increase which was sustained in 2013 (at this time there was an improvement in the economy). The TBR generated by the N-REITs industry within the study period seemed to be very small when compared to REIT industries of other nations such as the UK and Germany, which started their REIT industry the same year as Nigeria (that is in 2007). This could be attributable to the level of acceptability of REITs by investors in these countries as well as variation in the stability and strength of the economy of these nations as noted in a similar study by Olanrele et al. (2015).

Table 1: Total Business Revenues (TBR) of the N-REITs industry

\begin{tabular}{|c|c|c|c|}
\hline Year & \multicolumn{2}{|c|}{ N-REITs Annual TBR } & Number of Share Units \\
\hline & $\$$ & $\$$ & \\
\hline 2008 & $\$ 594,417,008$ & $\$ 1,942,539$ & $20,000,000$ \\
\hline 2009 & $\$ 1,918,470,009$ & $\$ 6,269,509$ & $270,019,781$ \\
\hline 2010 & $\$ 1,000,829,010$ & $\$ 3,270,683$ & $270,019,781$ \\
\hline 2011 & $\$ 1,145,809,971$ & $\$ 3,744,477$ & $270,019,781$ \\
\hline 2012 & $\$ 1,274,980,353$ & $\$ 4,166,602$ & $270,019,781$ \\
\hline 2013 & $\$ 1,102,936,216$ & $\$ 3,604,366$ & $270,019,781$ \\
\hline
\end{tabular}




\begin{tabular}{|c|c|c|c|}
\hline 2014 & $\$ 6,852,999,381$ & $\$ 22,395,422$ & $2,938,289,281$ \\
\hline 2015 & $¥ 6,907,443,855$ & $\$ 22,573,345$ & $2,938,289,281$ \\
\hline 2016 & $¥ 6,819,902,942$ & $\$ 22,287,264$ & $2,938,289,281$ \\
\hline Mean & $\$ \mathbf{3 , 0 6 8 , 6 4 3 , 1 9 4}$ & $\mathbf{\$ 1 0 , 0 2 8 , 2 4 5}$ & $\mathbf{1 , 1 3 1 , 6 6 2 , 9 7 2}$ \\
\hline
\end{tabular}

Source: Annual reports/statement of accounts and online database of Skye Shelter Fund, Union Homes REIT and UPDC REIT.

Note: The figures in parenthesis are the USD equivalent of the TBR within the study period (\$1 to \$306 at Central Bank of Nigeria' official exchange rate).

Table 2 presents the TIE on the conduct variables in the N-REITs industry within the study period. There was a sharp consistent decrease in the amount expended on advertisement from 2009 to 2015. The highest amount expended was in 2009 (9.7\%) of the TBR; while the lowest was in $2011(0.02 \%)$. There was some level of fluctuations in the amount expended on maintenance of properties in the N-REITs. The highest amount expended was in 2013 $(4.83 \%)$ while the least was in $2011(0.1 \%)$. There was a gradual but consistent increase in the amount expended on insurance of properties between 2009 and 2012; however in 2012 there was a gradual decrease until 2015. The highest amount expended was $2.64 \%$ in 2014, while the least expended within the study period was $0.54 \%$ in 2015. Administrative expenditure had the highest amount expended when compared to other variables. There was a consistent increase from 2008 to 2010, the figures decreased in 2011 and the decrease kept on till 2014. The highest amount expended on administrative expenditure was $28.6 \%$ in 2010 , while the least was $13.41 \%$ in 2015 . The mean percentage expenditure for advertisement, maintenance of properties, insurance of properties and administrative expenses were $1.2 \%, 1.7 \%, 1.3 \%$ and $20.0 \%$ respectively. Studies, such as Niskanen (2012) and Kaonga (2015), indicated that higher percentages of the companies' TBR were used in conduct activities. This implies that there may be need for Nigerian REITs to increase the amount expended on operation of conduct indicators. The data on Table 2 was used in analyzing the conduct of N-REITs using Equation 4.

Table 2: Total Individual Expenditure (TIE) in Percentage on Conduct Indicators in the N-REITs Industry

\begin{tabular}{|l|c|c|c|c|c|}
\hline Year & ADV & MP & IP & ADM & TOTAL \\
\hline 2008 & 0 & 0 & 0 & 13.94 & $\mathbf{1 3 . 9 4}$ \\
\hline 2009 & 9.74 & 0 & 0.74 & 15.14 & $\mathbf{2 5 . 6 2}$ \\
\hline 2010 & 0.36 & 2.33 & 0.88 & 28.6 & $\mathbf{3 2 . 1 7}$ \\
\hline 2011 & 0.02 & 0.1 & 0.81 & 25.39 & $\mathbf{2 6 . 3 2}$ \\
\hline 2012 & 0 & 2.23 & 2.26 & 23.06 & $\mathbf{2 7 . 5 5}$ \\
\hline 2013 & 0 & 4.83 & 1.45 & 20.85 & $\mathbf{2 7 . 1 3}$ \\
\hline 2014 & 0.59 & 3.37 & 2.64 & 24.62 & $\mathbf{3 1 . 2 2}$ \\
\hline 2015 & 0 & 0.8 & 0.54 & 13.41 & $\mathbf{1 4 . 7 5}$ \\
\hline 2016 & 0.87 & 1.64 & 1.92 & 14.89 & $\mathbf{1 5 . 0 7}$ \\
\hline Mean & $\mathbf{1 . 2}$ & $\mathbf{1 . 7}$ & $\mathbf{1 . 3}$ & $\mathbf{2 0 . 0}$ & $\mathbf{2 3 . 8}$ \\
\hline
\end{tabular}

Source: Analyses of survey data, 2017

Note: $A D V=$ Advertisement,$M P=$ Maintenance of Properties, $I P=$ Insuring of Properties, $A D M=$ Administrative expenses 
Table 3 presents data on the annual dividend and share prices of N-REITs covering a period from 2007 to 2016. From inception in 2007 to 2016, Skye Shelter Fund's share prices ranged between $\$ 18.55$ (\$0.322) and 117.42 (\$0.384) per share unit; and its dividend ranged between $\$ 4.04$ (\$0.013) and \$7.15 (\$0.023) per share unit. The share prices of the Union Homes REIT ranged between $\$ 45.55$ (\$0.149) and $\$ 50.00$ (\$0.163) per share unit within the study period. While its dividend ranged between $\$ 0.75$ (\$0.003) and $\$ 4.01$ ( $\$ 0.013$ ) per share unit. The UPDC REIT sold shares from $\$ 9.50$ (\$0.031) to 10.00 (\$0.033) per share unit from 2013 to 2016; with dividend payout that ranged between $\$ 0.23$ ( $\$ 0.001$ ) and $\$ 0.43$ (\$0.001) per share unit within the same investment period. The share prices and dividend of N-REITs is considered low when compared to other global REITs companies (Jackson, 2008; Naido, 2014). The share prices and dividends presented in Table 3 were used to calculate the performance of N-REITs (holding period returns) and the results are presented in Table 4.

Table 3: Annual Data on Dividend and Share Prices of N-REITs (in Naira) Companies from 2007 to 2016

\begin{tabular}{|c|c|c|c|c|c|c|c|c|}
\hline \multirow{2}{*}{ Year } & \multicolumn{2}{|c|}{ Skye Shelter Fund } & \multicolumn{2}{|c|}{ Union Homes REIT } & \multicolumn{2}{|c|}{ UPDC REIT } & \multirow{2}{*}{$\begin{array}{c}\text { N-REITs } \\
\text { Share }\end{array}$} & \multirow{2}{*}{$\begin{array}{c}\text { N-REITs } \\
\text { Dividend } \\
\end{array}$} \\
\hline & Share & Dividend & Share & Dividend & Share & Dividend & & \\
\hline 2007 & 100 & 0 & - & - & - & - & 100 & $0(0)$ \\
\hline 2008 & 117.42 & 4.65 & 50.00 & - & - & - & 167.42 & 4.65 \\
\hline 2009 & 103.21 & 7.00 & 50.00 & 4.01 & - & - & 153.21 & 11.01 \\
\hline 2010 & 99.55 & 6.40 & 50.85 & 0.75 & - & - & 150.4 & 7.15 \\
\hline 2011 & 98.55 & 4.04 & 50.00 & 2.27 & - & - & 148.55 & 6.31 \\
\hline 2012 & 100 & 5.00 & 50.00 & 2.13 & - & - & 150 & 7.13 \\
\hline 2013 & 100 & 5.25 & 50.00 & - & 10.00 & - & 160 & 15.25 \\
\hline 2014 & 98.56 & 5.80 & 48.54 & - & 9.50 & 0.31 & 156.6 & 6.11 \\
\hline 2015 & 100 & 7.15 & 45.55 & - & 9.78 & 0.43 & 155.33 & 7.58 \\
\hline 2016 & 100 & 5.3 & 50.00 & - & 10.00 & 0.23 & 160 & 0.23 \\
\hline
\end{tabular}

Source: Annual report and online data bases of Skye Shelter Fund, Union Homes REIT and UPDC REIT.

Note: The figures in parenthesis are the USD equivalent of the TBR within the study period (\$1 to 306 at Central Bank of Nigeria' official exchange rate).

Table 4 shows that, from the inception of the N-REITs companies up until 2016, the HHI of the N-REITs industry ranged between $41.81 \%$ (recorded in 2010 ) and $100 \%$ recorded in 2008 . This indicates a high concentration in the N-REITs industry which is characteristic of an oligopolistic market structure. In comparison, the US has over two hundred REIT companies operating in a perfectly competitive market structure. Similar REIT industries include the UK, Australia and Malaysia which have about 22, 52 and 15 REITs respectively (NAREIT, 2018). From Table 4 the highest amount expended on conduct indicators was $32.17 \%$ in the year 2010; while the lowest was in 2015 , with $0.02 \%$. There was some level of fluctuations in the amount expended on the conduct variables over the years. The highest amount expended was in 2013 (4.83\%), while the least was in 2011 (14.75\%). This could be attributable to the national economic recession experienced in 
Nigeria at this time. The performance of N-REITs in terms of holding period returns was observed to have fluctuated between $-0.24 \%$ and $22.07 \%$. The highest return value recorded was $22.07 \%$, obtained in 2008 . The least return value was recorded in $2014(-0.24 \%)$, and the mean value within the study period was $4.7 \%$. This is rather small when compared to other investment assets in Nigeria. For example, the 3 month's Treasury Bills provides a return of $8.5 \%$ and return on cash ranges between $4.5 \%$ and $10.5 \%$. Olanrele et al. (2018), in a study carried out to determine the causal relationship between $\mathrm{N}$ REITs dividend yield and Money Market Indicators (MMI) such as T-Bills and Currency in Circulation (CIC) found a short-run causal relationship between N-REITs dividend yield and MMI.

Table 4: Data on the Structure, Conduct and Performance of N-REITs Industry

\begin{tabular}{|l|c|c|c|}
\hline Year & $\begin{array}{c}\text { N-REIT } \\
\text { Structure }\end{array}$ & $\begin{array}{c}\text { N-REIT } \\
\text { Conduct }\end{array}$ & $\begin{array}{c}\text { N-REIT } \\
\text { Performance }\end{array}$ \\
\hline 2008 & 100 & 13.94 & 22.07 \\
\hline 2009 & 63.8 & 25.62 & 0.94 \\
\hline 2010 & 41.81 & 32.17 & 2.93 \\
\hline 2011 & 69.35 & 26.32 & 2.93 \\
\hline 2012 & 68.83 & 27.55 & 5.4 \\
\hline 2013 & 64.12 & 27.13 & 2.63 \\
\hline 2014 & 70.69 & 31.22 & -0.24 \\
\hline 2015 & 67.97 & 14.75 & 2.86 \\
\hline 2016 & 68.94 & 16.98 & 2.93 \\
\hline Mean & 68.39 & 23.9 & 4.7 \\
\hline
\end{tabular}

Source: Analysis of survey data, 2017

Table 5 presents the descriptive statistics of the structure, conduct and performance variables of the N-REITs industry. It shows the mean, minimum and maximum values of the variables. It also shows the standard deviation, skewness and kurtosis for each of the variables. Table 6 presents the Granger Causality test for the structure, conduct and performance of N-REITs.

Table 5: Descriptive Statistics of the Structure, Conduct and Performance Variables of N-REITs Industry

\begin{tabular}{|l|c|c|c|}
\hline \multicolumn{1}{|c|}{ Statistics } & $\begin{array}{c}\text { N-REIT } \\
\text { Structure }\end{array}$ & $\begin{array}{c}\text { N-REIT } \\
\text { Conduct }\end{array}$ & $\begin{array}{c}\text { N-REIT } \\
\text { Performance }\end{array}$ \\
\hline Mean & 68.39 & 23.96 & 4.7 \\
\hline Std. Deviation & 14.80 & 6.94 & 6.7 \\
\hline Skewness & -1.3 & -1 & 0.7 \\
\hline Kurtosis & 0.3 & -1 & 1.7 \\
\hline Minimum & 41.81 & 13.94 & -0.24 \\
\hline Maximum & 100 & 32.17 & 22.07 \\
\hline
\end{tabular}

Source: Analysis of survey data, 2017

The computed KPSS and PP test-statistics as seen in Table 6 are integrated of order I(0). It was observed that the KPSS and PP statistics were smaller 
than the critical values - "tau" at 10\%, 5\%, and 1\% significance levels respectively. Therefore we can reject Ho for the SCP variables. This means that the data series are all stationary series at $10 \%, 5 \%$ and $1 \%$ significance levels and are integrated of order $\mathrm{I}(0)$ at level. In order to analyze the relationships among the structure, conduct and performance of N-REITs; Equations 9, 10 and 11 were used in line with previous studies such as Zietz, Sirmans and Friday (2003), Tung et al, (2010) and Kaonga (2015). The results are presented in Table 8 .

Table 6: KPSS and PP Unit Root Test on Data for the Structure, Conduct and Performance of N-REITs

\begin{tabular}{|l|c|c|c|c|c|c|c|c|}
\hline $\begin{array}{l}\text { SCP } \\
\text { Variables }\end{array}$ & $\begin{array}{c}\text { KPSS } \\
\text { Statistics }\end{array}$ & $\begin{array}{c}\mathbf{1 \%} \\
\text { Critical } \\
\text { Value }\end{array}$ & $\begin{array}{c}\mathbf{5 \%} \\
\text { Critical } \\
\text { Value }\end{array}$ & $\begin{array}{c}\mathbf{1 0 \%} \\
\text { Critical } \\
\text { Value }\end{array}$ & $\begin{array}{c}\text { PP } \\
\text { Statistics }\end{array}$ & $\begin{array}{c}\mathbf{1 \%} \\
\text { Critical } \\
\text { Value }\end{array}$ & $\begin{array}{c}\mathbf{5 \%} \\
\text { Critical } \\
\text { Value }\end{array}$ & $\begin{array}{c}\mathbf{1 0 \%} \\
\text { Critical } \\
\text { Value }\end{array}$ \\
\hline N-REIT Structure & $0.225299^{*}$ & 0.739 & 0.463 & 0.347 & $-4.2413^{*}$ & -4.18265 & -3.32097 & -2.80138 \\
\hline N-REIT Conduct & $0.202396^{*}$ & 0.739 & 0.463 & 0.347 & $-3.8771^{*}$ & -5.60462 & -3.69485 & -2.98281 \\
\hline N-REIT Performance & $0.346833^{*}$ & 0.739 & 0.463 & 0.347 & $-12.523^{*}$ & -4.58265 & -3.32097 & -2.80138 \\
\hline
\end{tabular}

Source: Analysis of survey data, 2017

Note: *= Stationary at level

Table 7 presents the results of the Granger Causality tests of the N-REITs industry, and Figure 1 shows the causal relationships among the structure, conduct and performance of N-REITs. The results obtained indicated a bidirectional Granger Causality for the N-REITs industry. This implies that there is a two-way positive relationship existing among the structure, conduct and performance of N-REITs. This means that the structure of N-REITs affects both the conduct (with P-value as 0.0244) and performance (with Pvalue as 0.0073 ) of the N-REITs industry. Similarly, the conduct of N-REITs also affects both the structure (with P-value as 0.0480) and performance (with $\mathrm{P}$-value as 0.0045) of the N-REITs industry. By the same token, the performance of the N-REITs also affected the structure (with P-value as 0.0372) and conduct (with P-value as 0.0078 ) of the N-REITs industry. This is congruent with what was found in literature as confirmed by studies such as Porter (1981) and Mu'azu et al. (2013) which posited that the SCP concept has a reverse causal relationship referred to as 'feedback'. However, this refutes the hypothesis postulated by Bain (1951).

Table 7: Granger Causality Tests for Structure, Conduct and Performance Components of N-REITs industry

\begin{tabular}{|l|c|c|}
\hline Null Hypothesis: & F-Statistic & P-Value \\
\hline N_REIT_PERF does not Granger Cause N_REIT_COND & 0.65565 & 0.0078 \\
\hline N_REIT_COND does not Granger Cause N_REIT_PERF & 0.01585 & 0.0045 \\
\hline N_REIT_STRU does not Granger Cause N_REIT_COND & 4.24982 & 0.0244 \\
\hline N_REIT_COND does not Granger Cause N_REIT_STRU & 7.63015 & 0.0480 \\
\hline N_REIT_STRU does not Granger Cause N_REIT_PERF & 0.23871 & 0.0073 \\
\hline N_REIT_PERF does not Granger Cause N_REIT_STRU & 1.79972 & 0.0372 \\
\hline
\end{tabular}

Source: Analysis of survey data, 2017 


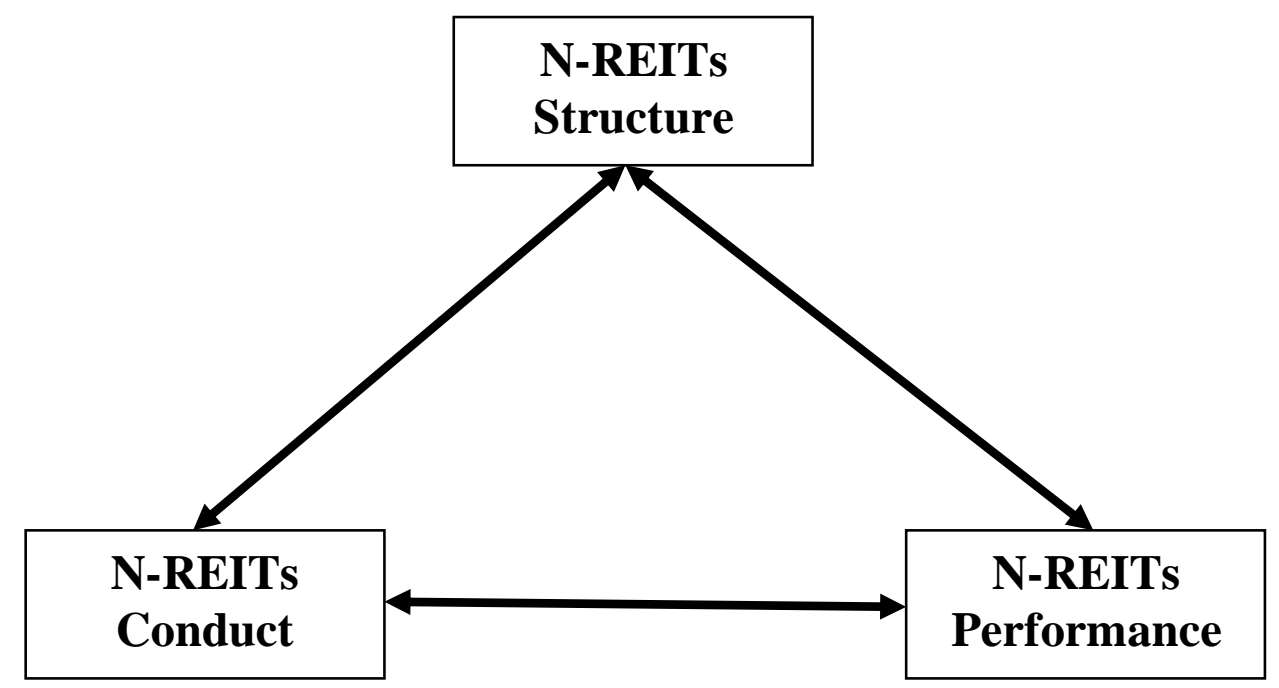

Figure 1: Bi-directional Causality Relationships among the Structure, Conduct and Performance of N-REITs.

Table 8 shows the regression analysis of the structure, conduct and performance of N-REITs. When the structure component of the SCP was used as a dependent variable, the regression results indicated a strong positive correlation of 0.753 between all the variables, with a coefficient of determination $\left(\mathrm{R}_{2}\right)$ of 0.567 meaning that the model explains $56.7 \%$ of the variance in the dependent variable by the independent variables in the $\mathrm{N}$ REITs industry. Looking at the significance values of the individual $\beta$ 's, it was revealed that all the predictors, i.e. performance and conduct, significantly predicted the structure of N-REITs with $\mathrm{t}=2.312 ; \mathrm{p}=0.045<0.05$; and $\mathrm{t}=0.147 ; \mathrm{p}=0.008<0.01$ respectively. Hence they are statistically significant (note that 0.05 and 0.01 above indicates the significance levels at $5 \%$ and $10 \%$ respectively).

When conduct was used as the dependent variable and structure and performance as the independent variables, the regression result indicated a strong positive correlation of 0.817 between all the variables, with a coefficient of determination $\left(\mathrm{R}_{2}\right)$ of 0.667 . The beta coefficients of the individual $\beta$ 's showed that all the predictors significantly predicted the conduct of N-REITs with $\mathrm{t}=-1.352 ; \mathrm{p}=0.025<0.05 ;$ and $\mathrm{t}=2.312$; $\mathrm{p}=0.045<0.05$ respectively. Hence they are statistically significant at both $5 \%$ and $10 \%$ level of significance.

When performance was used as the dependent variable and structure and conduct as the independent variables, results from the regression analysis indicated a positive correlation of 0.611 between all the variables, with a coefficient of determination $\left(\mathrm{R}_{2}\right)$ of 0.373 . From the significance values of the individual $\beta$ 's, it was shown that both structure and conduct significantly predicted the performance of N-REITs with $\mathrm{t}=0.147$; $\mathrm{p}=0.008<0.01$; and $\mathrm{t}=$ $1.352 ; \mathrm{p}=0.025<0.05$ respectively. Hence they are statistically significant at both $5 \%$ and $10 \%$ level of significance accordingly. 
From the analysis above, it is evident that there exists a strong positive relationship among the structure, conduct and performance of N-REITs. This finding is congruent with other similar studies in the real estate industry such as, Chan et al. (2003), Ogunba (2004) and Tung et al. (2010). The implication of this for the REITs industry is the need to ensure that the respective REIT companies are properly structured and conduct activities given priority to enhance performance, as the study revealed that both structure and conduct influence performance and vise-versa. This information can be used by stakeholders in the real estate industry such as pension funds, asset managers, individual investors and insurance companies in making informed investment decisions.

Table 8: Regression Analysis of the Structure, Conduct and Performance of N-REITs Industry

\begin{tabular}{|c|c|c|c|c|c|c|c|}
\hline Dependent & Independent Variables & $\mathbf{R}$ & $\mathbf{R}_{2}$ & Beta & $\mathbf{T}$ & P-Value & Level of \\
\hline \multirow{3}{*}{$\begin{array}{l}\text { N-REITs } \\
\text { Structure }\end{array}$} & & 0.753 & 0.567 & & & & \\
\hline & \multicolumn{2}{|l|}{ N-REITs Conduct } & & 2.67 & 2.312 & 0.045 & 0.05 \\
\hline & \multicolumn{3}{|l|}{ N-REITs Performance } & 0.355 & 0.147 & 0.008 & 0.01 \\
\hline \multirow{3}{*}{$\begin{array}{l}\text { N-REITs } \\
\text { Conduct }\end{array}$} & & 0.817 & 0.667 & & & & \\
\hline & \multicolumn{2}{|l|}{ N-REITs Structure } & & 0.176 & 2.312 & 0.045 & 0.05 \\
\hline & \multicolumn{3}{|l|}{ N-REITs Performance } & -0.736 & 1.352 & 0.025 & 0.05 \\
\hline \multirow{3}{*}{$\begin{array}{l}\text { N-REITs } \\
\text { Performance }\end{array}$} & & 0.611 & 0.373 & & & & \\
\hline & \multicolumn{2}{|l|}{ N-REITs Structure } & & 0.01 & 0.147 & 0.008 & 0.01 \\
\hline & \multicolumn{2}{|l|}{ N-REITs Conduct } & & -0.317 & -1.352 & 0.025 & 0.05 \\
\hline
\end{tabular}

Source: Analysis of survey data, 2017

\section{Conclusion}

This study used Bain's Structure, Conduct and Performance (SCP) model to examine N-REITs and found a positive significant and bi-directional causal relationship among the structure, conduct and performance of REITs in Nigeria. This is congruent with what was found in the literature as confirmed by studies such as Ogunba (2004) and Mu'azu et al. (2013). However, this disagrees with the hypothesis postulated by Bain (1951) which purports that there is a one-way causal relationship between the structure, conduct and performance of firms/industries. The implication of this result to the N-REITs industry is that to improve the performance of the industry the respective companies in the industry must be properly structured. Similarly, conduct indicators, such as advertisement, should be given priority. The study also provides essential information for stakeholders in the real estate sector regarding the influence of structure and conduct on the performance of $\mathrm{N}$ REITs. This information will be valuable for equipping asset managers, insurance companies, pension funds as well as individual real estate investors in making informed investment decisions.

This is also congruent with findings of previous studies such as Tung et al. (2010), Nabieu (2013) and Kaonga (2015). The study concluded that the below optimal performance of N-REITs was traced to the deficiencies inherent in the internal factors impacting on the N-REITs industry as it relates 
to the structure and conduct in the N-REITs industry. This suggests that there is a need to improve in the aforementioned areas. This is pertinent because the study revealed that there is a strong positive bi-directional relationship among the structure, conduct and performance of N-REITs. The study is limited by the number of observations used with respect to the available data. This is because REITs are still new in Nigeria when compared to other REITs industries such as the US and hence provided limited data from inception to date. Data covering a longer period of time could present a better picture of the REITs industry in Nigeria.

\section{References}

Abdul Majid, M.Z. \& Sufian, F. (2007). Market structure and competition in emerging market: Evidence from Malaysian Islamic banking industry. Journal of Economic Cooperation, 28(2), pp.99-121. Available at: http://www.sesric.org/pdf.php?file=ART07010105-2.pdf

Aik, N. (2012). Malaysian real estate investment trusts (M-REITs) and the financial crisis: A performance and comparative analysis. International Journal of Research in Commerce and Management, 3(1), pp.13-19.

Akinsomi, O., Balcilar, M., Demirer, R. \& Gupta, R. (2017). The effect of gold market speculation on REIT returns in South Africa: a behavioral perspective. Journal of Economics and Finance, 41(4), pp.774-793.

Akinsomi, O., Kola, K., Ndlovu, T. \& Motloung, M. (2016). The performance of the broad based black economic empowerment compliant listed property firms in South Africa. Journal of Property Investment and Finance, 34(1), pp.3-26.

Akpan, U.E. \& Ogunba, A.O. (2015). Real estate finance and investment: An evaluation of foreign direct and indirect property investment opportunity in Africa. Proceedings of the 15th African Real Estate Society (AFRES) Annual Conference, 31st August-3rd September 2015, Kumasi, Ghana, pp.90-110.

Ankeli, I.A., Dabara, I.D., Omotehinshe, O.J., Adamu, M.K. \& Adaranijo, L.O. (2017). Assessment of Housing Condition and its Effect on Occupiers' Health Condition. The 12th International Conference on Advances in Science, Humanities and Education, 12th-13th September, 2017. Republic of Benin. pp.57-64.

Aro-Gordon, S.O., Bashir, A.M., Abdulsalam, D.O. \& Abdullahi, H. (2014). An assessment of recent market performance of REITs in a Developing Economy. Journal of Business and Management, 16(8), pp.16-21.

Bain, J.S. (1951). Relation of profit rate to industry concentration: American manufacturing, 1936-1940. The Quarterly Journal of Economics, 65(3), pp.293-324.

Bekaert, G., Harvey, C.R. \& Lundblad, C.T. (2003). Equity market liberalization in emerging markets. The Journal of Financial Research, 26(3), pp. 275-299. Available at: https://public.kenanflagler.unc.edu/faculty/lundblac/equity_market_1 iberalization.pdf 
Bhandari, A.K. (2010). Concentration, entry barriers and profitability in the Indian industries: an empirical analysis. Journal of Quantitative Economics, 8(2), pp.61-80. Available at:

http://www.jqe.co.in/journals/JQE_v8_n2_2010_p5.pdf

Bhattacharya, M. (1997). The specifications and testing of StructureConduct-Performance relationships in Australian Manufacturing. A thesis submitted for the Degree of Doctor of Philosophy in the Department of Economics, The University of Tasmania, Australia.

Chan, S.H., Erickson, J. \& Wang, K. (2003). Real estate investment trusts: structure, performance and investment opportunities. New York: Oxford University Press.

Dabara, I.D., Ogunba, A.O. \& Araloyin, F.M. (2015). The Diversification and Inflation- Hedging Potentials of Direct and Indirect Real Estate Investments in Nigeria. Proceedings of the 15th African Real Estate Society (AFRES) Annual Conference, 31st August-3rd September 2015, Kumasi, Ghana. pp.169-185.

Dabara, I.D. \& Oyewole M.O. (2015). The trends in commercial property values in an emerging real estate market: The case of Ibadan metropolis, Nigeria. Proceedings of the $15_{\text {th }}$ African Real Estate Society (AFRES) Annual Conference, 31st August-3rd September 2015. Golden Tulip, Kumasi, Ghana. pp.186-205.

Dabara, I.D., Tinufa, A.A., Soladoye, J.O., Ebenezer, O.O. \& Omotehinshe, O.J. (2018). Financial structure of REITs in emerging property markets: An assessment of N-REITs. Research Journal of Finance and Accounting, 9(16), pp.30-38. Available at:

https://www.iiste.org/Journals/index.php/RJFA/article/download/43 $836 / 45169$

Dabara, I.D., Omotehinshe, O.A., Chiwuzie, A., Asa, O.A. \& Soladoye, J.O. (2018). The market structure of Real Estate Investment Trusts in Nigeria. Proceedings of the Conference of the International Journal of Arts \& Sciences (IJAS), University of Freiburg, Germany. 3rd-6th December, 2018. pp.101-112. Available at:

http://www.universitypublications.net/proceedings/1103/html/DE8C 390.xml

Dabara, I.D., Chiwuzie, A. Omotehinshe, O.J., Tinufa, A. \& Soladoye, J.O. (2019). Analysis of the relationship between inflation and indirect real estate investments in Nigeria. Proceedings of the 19th African Real Estate Society (AFRES) Annual Conference, 10th to 13th September, 2019, Arusha International Conference Center, Tanzania, pp.112-237.

Delorme, C.D., Klein, P.G., Kamerschen, D.R. \& Voeks, L.F. (2002). Structure, Conduct and Performance: A Simultaneous Equations Approach. Applied Economics, 35, pp.13-20.

Drew, A. (2016). Preserving existing affordability through a social purpose REIT. Journal of case study research, 1(1), pp.39-41.

Ferguson, R.R. (1998). The structure-conduct-performance paradigm. In: Industrial Economics: Issues and Perspectives. London: Palgrave.

Gavurova, B., Kocisova, K., Kotaskova, A. (2017). The Structure - Conduct - Performance Paradigm in the European Union Banking. Economics and Sociology, 10(4), pp.99-112. Available at: https://economicssociology.eu/files/12_08_469_Gavurova_Kocisova_Kotaskova.pdf 
Ijasan, K., Tweneboah, G. \& Mensah, J.O. (2017). Anti-persistence and longmemory behaviour of SAREITs. Journal of Property Investment \& Finance, 35(4), pp.356-368.

Jackson, L.A. (2008). The structure and performance of US hotel real estate investment trusts. Journal of Retail and Leisure Property, 7(4), pp.275-290.

Kaonga, K. (2015). Market structure, conduct and performance of firms in the insurance industry: Evidence from Zambia. A thesis submitted in partial fulfillment of the requirement for the award of the degree of Master of Arts, University of Zambia.

Kambhampati, U. (1996). Industrial concentration and performance. Delhi: Oxford University Press.

Khoipham, A. (2013). An empirical analysis of real estate investment trusts in Asia: Structure, performance and strategic investment implications. A thesis submitted in fulfillment of the requirement for the degree of Doctor of Philosophy at the University of Western Sydney.

Kloosterman, R.M. (2009). The Inflation-hedging characteristics of real estate investment trusts. Master thesis submitted to Department of Finance, Erasmus Universiteit Rotterdam. Available at:

http://oaithesis.eur.nl/ir/repub/asset/5361/306020kloostermanma0609.pdf

Kwoka, J.E. (2007). Large firm dominance and price-cost margins in manufacturing industries. Southern Economic Journal, 44(1), pp.183189.

Lee, C.C. (2012). The causal correlations among market structure, conduct and performance of the CPA industry. The Services Industries Journal, 32(3), pp.431-450.

Li, R.Y. \& Chow, H. P. (2015). An economic analysis on REIT cycles in nine places. Real Estate Finance, 3(2), pp.23- 28.

Macarena, E. \& Davide, F. (2014) Advertising Effectiveness: An Approach Based on What Consumers Perceive and What Advertisers Need. Open Journal of Business and Management, 2, pp.180- 188. Available at: http://file.scirp.org/pdf/OJBM_2014070417115245.pdf

Manoj, P.K. (2016). Real Estate Investment Trusts (REITs) for faster housing development in India: An analysis in the context of the new regulatory policies of SEBI. International journal of Advance Research in Computer science and Management Studies, 4(6), pp.152-167. Available at:

http://www.ijarcsms.com/docs/paper/volume4/issue6/V4I6-0088.pdf

Mason, E. (1939). Price and production policies of large scale enterprise. American Economic Review, 29(1), pp.61-74.

Matyjas, Z. (2014). The role of the structure-conduct- performance paradigm for the development of industrial organization economics and strategic management. Journal of Positive Management, 5(2), pp.5363. Available at: file:///c:/users/dell/downloads/3879-12263-1-sm.pdf

Mu'azu, A.U., Mohammed, Z., Shamsudin, M.N. \& Abdullatif, I. (2013). Structure-Conduct-Performance of Malaysian Poultry industry. Australian Journal of Basic and Applied Science, 7(8), pp.170-177.

Naidoo, H. (2014). The introduction of REITs to the South African property market: Opportunities for fund managers. A thesis submitted to the 
University of the Witwatersrand, in fulfillment of the requirements for the degree of Masters of Management in Finance and Investments.

Nabieu, G.A. (2013). The structure, conduct and performance of commercial banks in Ghana. European Journal of Business and Innovation Research, 1(4), pp.34-47.

NARIET, (2018). REIT market data, retrieved in August 2018. Available at: https://www.reit.com/nareit

NARIET, (2019). REIT market data, retrieved in May 2019. Available at: https://www.reit.com/nareit

Niskanen, J. (2012). European Real Estate Investment Trusts. A dissertation submitted to Aalto University Espoo, Finland, in partial fulfillment for the award of Doctor of Science in Technology. Available at:

http://lib.tkk.fi/Diss/2012/isbn9789526049137/isbn9789526049137.pdf

Ntuli, M. \& Akinsomi, O. (2017). An Overview of the Initial Performance of the South African REIT Market. Journal of Real Estate Literature, 25(2), pp.365-388.

Ogunba, O. A. (2004). 'The demand for accuracy in valuations: The case of Nigeria'. Proceedings of the International Symposium on Globalization and Construction, Thailand, pp.679-688.

Olanrele, O.O. (2014a). REIT performance analysis: Are other factor determinants constant? Asisan Economic and Financial Review, 4(4), pp.492-502.

Olanrele, O.O., Adegunle, T.O. \& Fateye, O.B. (2018). Causal relationship of N-REITs dividend yield and money market indicators: A case study of Skye Shelter REITs. Proceedings of the 18th African Real Estate Society (AFRES) Annual Conference, 11 th to 15th September, 2018, Abeokuta, Nigeria. pp. 307 - 328.

Olanrele, O.O., Said, R., \& Daud, N. (2015). An evaluation of the performance and acceptability of REIT in Nigeria. Proceedings of the15th African Real Estate Society (AFRES) Annual Conference, $31_{\text {st }}$ August to 3rd September 2015, Kumasi Ghana. pp.269-286.

Porter, M.E. (1981) Competitive Strategy; Free Press, New York Public Account - Thirty Fifth Report House of Commons, UK. Available at:

http://www.publications.parliament.uk/pa/cm200203/cmselect/cmpu bacc/567/56702.htm

Ray, M.A. (1992). Economic education, experiment methods and the structure-conduct-performance paradigm. The American Economist, 36(2), pp.66-71.

Seguin, P.J. (2016). The relative value of public non-listed REITs. Journal of Real Estate Research (JRER). 38(1), pp.59-92.

Scherer, F.M. \& Ross, D. (1990). Industrial Market Structure and Economics Performance. Boston: Houghton Mifflin Company.

Skye Shelter Fund. (2007). Annual report and statement of accounts Report presented at the Annual General Meeting of shareholders of Skye Shelter Fund in Lagos, Nigeria.

Surminski, S. (2014) The role of insurance in reducing direct risk: the case of flood insurance. International Review of Environmental and Resource Economics, 7(3), pp.241-278. Available at: 
http://eprints.lse.ac.uk/60764/1/Surminski_Role-of-insurancereducing-direct-risk_2014.pdf

Tung, G., Lin, C. \& Wang, C. (2010). The market structure,conduct and performance paradigm re-applied to the international tourist hotel industry. African Journal of Business management, 4(6), pp.11161125.

Union Home REITs. (2008). Annual Report and Statement of Accounts. Report presented at the Annual General Meeting of shareholders of Union Home REITs in Lagos, Nigeria.

UPDC REITs. (2013). Annual Report and Statement Accounts. Report presented at the Annual General Meeting of shareholders of UPDC REITs in Lagos, Nigeria.

Zietz E.N., Sirmans G. \& Friday H. (2003). The environment and performance of real estate investment trusts. Journal of Real Estate Portfolio Management, 9(2), pp.127-165. 